\title{
Correction to: The $L s V e 1 L$ allele provides a molecular marker for resistance to Verticillium dahliae race 1 in lettuce
}

Patrik Inderbitzin ${ }^{1,2+}$, Marilena Christopoulou ${ }^{3 \dagger}$, Dean Lavelle 3 , Sebastian Reyes-Chin-Wo ${ }^{3}$, Richard W. Michelmore ${ }^{3,4}$, Krishna V. Subbarao ${ }^{1 *}$ and Ivan Simko ${ }^{5^{*}}$

\section{Correction to: BMC Plant Biol (2019) 19:305 https://doi.org/10.1186/s12870-019-1905-9}

Following publication of the original article [1], the author reported a processing error in Fig. 5. This has been corrected in the original article.

The correct version of Fig. 5 is also shown in this correction.

In the Additional file 7, the sequence data for LsVe3L and LsVe4L were swapped. The correct Additional file 7 is shown in the Additional file section below.

\section{Additional file}

Additional file 7: Nucleotide sequences of six LsVe alleles from cultivars La Brillante (L) and Salinas (S). (DOCX $17.8 \mathrm{~kb})$

\section{Author details}

${ }^{1}$ Department of Plant Pathology, University of California, Davis, CA 95616, USA.

${ }^{2}$ Present address: Indigo Ag, Charlestown, MA 02129, USA. ${ }^{3}$ Genome Center, University of California, Davis, CA 95616, USA. ${ }^{4}$ Departments of Plant Sciences, Molecular \& Cellular Biology, Medical Microbiology \& Immunology, University of California, Davis, CA 95616, USA. ${ }^{5}$ United States Department of Agriculture,

Agricultural Research Service, Crop Improvement and Protection Research Unit, Salinas, CA 93905, USA.

Published online: 26 August 2019

\section{Reference}

1. Inderbitzin $P$, et al. The LSVeIL allele provides a molecular marker for resistance to Verticillium dahliae race 1 in lettuce. BMC Plant Biol. 2019; 19:305. https://doi.org/10.1186/s12870-019-1905-9.

\footnotetext{
* Correspondence: kvsubbarao@ucdavis.edu; Ivan.Simko@ars.usda.gov ${ }^{+}$Patrik Inderbitzin and Marilena Christopoulou contributed equally to this work. ${ }^{1}$ Department of Plant Pathology, University of California, Davis, CA 95616, USA ${ }^{5}$ United States Department of Agriculture, Agricultural Research Service, Crop Improvement and Protection Research Unit, Salinas, CA 93905, USA Full list of author information is available at the end of the article
}

(c) The Author(s). 2019 Open Access This article is distributed under the terms of the Creative Commons Attribution 4.0 International License (http://creativecommons.org/licenses/by/4.0/), which permits unrestricted use, distribution, and reproduction in any medium, provided you give appropriate credit to the original author(s) and the source, provide a link to the Creative Commons license, and indicate if changes were made. The Creative Commons Public Domain Dedication waiver (http://creativecommons.org/publicdomain/zero/1.0/) applies to the data made available in this article, unless otherwise stated. 


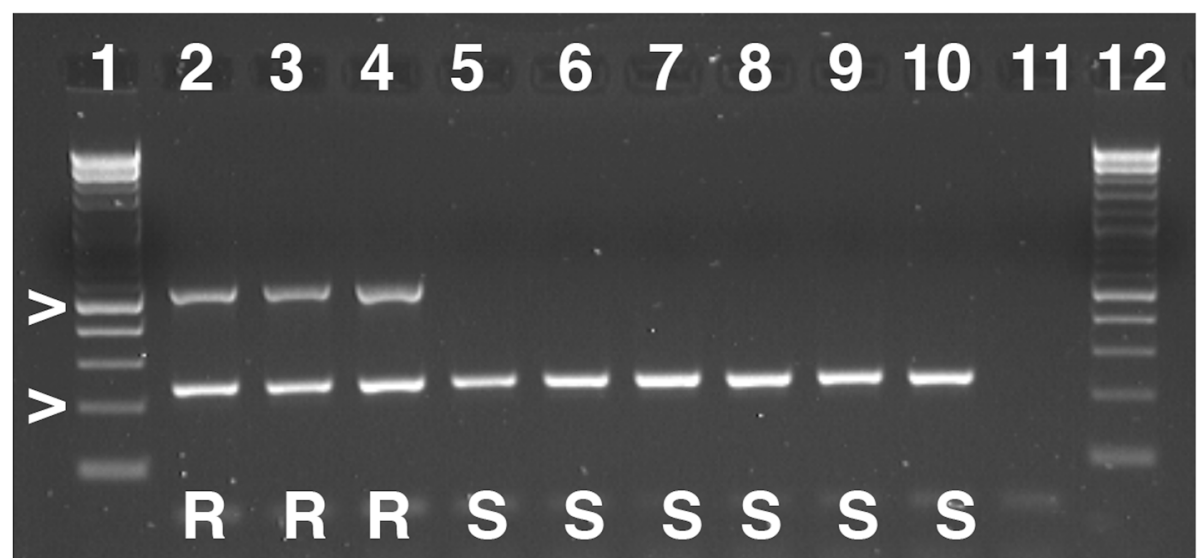

Fig. 5 LSVelL specific PCR assay is allele-specific. Shown are results of LsVelL-specific PCR assays with selected lettuce accessions with known LsVe genotypes and resistance phenotypes. Resistance (R) and susceptibility (S) is indicated by capital letters for each accession. In all cases, the outcomes of the PCR assays were as expected from genome sequencing. Amplicon sizes are indicated by $>$ and correspond to 200 and 500 bp. Lane numbers are: 1. 2-log ladder, 2. cultivar Balady Banha (Ve genotype: LSVe1L, LSVe3L, LSVe4L), 3. cultivar Lolla Rossa (LsVe1L, LsVe3L, LsVe4L), 4. cultivar Plymouth (LsVe1L, LsVe3L, LsVe4L), 5. cultivar Cobham Green (LsVe3L, LsVe4L, LsVe1S, LsVe2S), 6. cultivar Lee Tal (LsVe4L, LsVe1S, LsVe2S), 7. cultivar Margarita (LSVe4L, LsVe1S, LsVe2S), 8. cultivar Anuenue (LsVe2S, LsVe3S), 9. cultivar Blonde Lente a Monter (LsVe1S, LsVe2S, LsVe3S), 10. cultivar Primus (LsVe1S, LsVe2S, LSVe3S), 11. negative control, and 12. 2-log ladder. PCR conditions are described in Table 4 